\title{
Viking Mortuary Citations
}

\author{
Howard Williams
}

Williams, H. 2016. Viking mortuary citations, European Journal of Archaeology 19(3): 400-14. http://dx.doi.org/10.1080/14619571.2016.1186882

\begin{abstract}
Introducing the European Journal of Archaeology's special issue 'Mortuary Citations: Death and Memory in the Viking World', this article outlines the justification and theoretical framework underpinning a new set of studies on Viking-age mortuary and commemorative practice as strategies of mortuary citation. The contributions to the collection are reviewed in relation to strengths and weaknesses in existing research and broader themes in mortuary archaeological research into memory work in past societies.
\end{abstract}

\section{Keywords}

Early Medieval, Viking Age, Iron Age, Insular/British Isles, Scandinavia, death, commemoration, memory, mortuary practice

\section{Introduction}

This special issue explores death and memory in the Viking world, taking as its core the concept of citation as a mnemonic strategy in mortuary practice, connecting past, present, and future. A number of archaeologists have intermittently explored the citations within mortuary practice, evidenced at a range of scales: the choice of items selected for deposition with the dead; the posture and transformation of the body itself the citational dimensions to augmenting, adapting, and reusing monuments; the spatial and material relationships between graves and monuments within cemeteries; and their landscape settings. Yet these issues have not been explored in depth and across media, and certainly have not been systematically explored for the Viking Age.Over recent decades, the study of memory in mortuary practice and commemorative monuments has flourished, but how citations worked between materials and contexts in establishing and reproducing the character of social memory has received relatively limited attention.

This issue of the European Journal of Archaeology was inspired by two sessions at international archaeology conferences organized by Dr Nanouschka Myrberg Burström (Stockholm University) and this author: 'Chains of Citation: re-contextualization in the Viking Age' (EAA annual conference, University of Western Bohemia, Pilsen, Czech Republic, 4-8 September 2013) and 'Material Citations in the Viking Age' (14th Nordic Theoretical Archaeology Group conference, Stockholm University, Stockholm, Sweden, 22-26 April 2014). Both aspired to consider the use, reuse, and re-contextualization of material culture in the Viking world (northern Europe between the eighth and eleventh centuries AD), focusing on the concept of citation. By citation, we do not only mean the conscious symbolic and material allusions to material pasts. In addition, citations may not have been initially intentional. They might instead involve the cumulative and unanticipated relationships that accrue through the assembling and juxtaposition, deposition, and transformation of artefacts, bodies, graves, and monuments. This approach does not follow a single theoretical framework, but interleaves a range of 
themes in recent mortuary and memory theory, including approaches to ritual practice, cultural biographies of things and monuments, and the material turn in archaeological research emphasizing the entangled and enmeshed relationships between people and things (Hall 2015; Williams et al., 2015). In focusing on the Viking Age provides a rich seam of material to which these theoretical approaches are applicable but have hitherto been neglected. For Viking studies, this approach promises to straddle local and contextualized investigations, as well as macro-scale interactions and networks that connected the islands of the North Atlantic, Northern Europe, and the Mediterranean world.

Including articles drawn from session papers (Hall; Williams) and especially commissioned additional pieces (Eriksen, Klevnäs, Lund \& Arwill-Nordbladh) this special issue builds upon, but differs from, the conference sessions in three further ways. First, the focus here is specifically on mortuary contexts as one key environment for the construction and reproduction of social memories among Viking-age communities. Second, we direct our attention to citations as a principal strategy hitherto under-valued in studies of Viking-age mortuary practice. Finally, the special issue benefits from a closing commentary (Back Danielsson) that develops the debate in relation to post-humanist approaches in archaeology and cognate disciplines. In these three regards, the articles here contain individual original studies and reinterpretations mortuary and commemorative practice from Scandinavia and the islands of the North Atlantic. Furthermore, the articles in combination provide a unique collection of interest to students and scholars of both the Viking Age and mortuary archaeology. This introduction seeks to frame the collection in relation to recent research in Viking-age burial archaeology and carved stone monuments, as well as to situate these studies in connexion with broader themes and debates in mortuary archaeology.

\section{The Diversity of Viking Death-Ways}

The variety of mortuary and commemorative practices throughout the Viking world is bewildering, revealing the meshwork of intersections between Scandinavia, the Baltic, northern Europe, the Byzantine, and Islamic worlds and the islands of the North Atlantic which both created, and were created by, the Viking diaspora (Harrison, 2007; Price, 2008; 2010). There has been no shortage of exciting new discoveries and research on late first millennium AD funerary remains and commemorative monuments over recent decades (Rundkvist, 2007). Data including graves and cemeteries, burial mounds, rune-stones, sculpted stone crosses, and recumbent grave-covers as well as cultic buildings, artefacts, art, and amulets have been widely investigated, reported, and incorporated into wider interdisciplinary research in Viking studies on practices and perceptions of death, burial, commemoration, and the afterlife. Operating on multiple scales, from studies of individual graves and monuments, burial sites and locales, landscapes, regional surveys, and macroregional explorations, mortuary archaeologies of the late first millennium are rich, varied, and keyed into broader archaeological and historical debates. These include the use of mortuary evidence to explore socio-political, economic, and ideological changes within Scandinavia, Europe, and further afield between the eighth and eleventh centuries. In addition, many local or regional sites, monuments, and archaeological contexts have particularly important contributions to make. 
Recent mid- to late-first-millennium AD burial studies (including those of the eighth to eleventh centuries) have been the subject of profitable and healthy debates and innovative interpretations. These have revolved around reanalyses and reinterpretations of finds and sites long familiar to scholars, including large burial assemblages and cemetery analyses as well as wealthy chamber-graves and boat-graves (e.g. Staecker, 2005; Ljungkvist, 2008; Gräslund \& Ljungkvist, 2011; Nordeide, 2011; Bill \& Daly, 2012; Harrison \& Ó Floinn, 2014; Hedenstierna-Jonson, 2015; Klevnäs, 2015). Yet across Scandinavia and areas affected by the Viking diaspora, new discoveries, and methods have driven forward research on burial sites and their environs (e.g. Artelius \& Kirstensson, 2005; Artelius \& Lindqvist, 2005; Rundkvist \& Williams, 2008; Paterson et al., 2014; Jessen et al., 2015). Equally important, especially in the context of this collection, Viking-age mortuary archaeology has developed over the last decade as a profitable arena for debating new theoretical frameworks for enquiry (e.g. Goldhahn \& Oestigaard, 2008; Pétursdóttir, 2009; Price, 2010; Eriksen, 2013; Gardeła, 2016). This work is important, since in many regards Viking-age mortuary archaeology has largely remained within a pre-1970s culture-historic framework of identifying shared cultural beliefs of migrants, approaches that persist in many fieldwork reports and popular syntheses of the mortuary data.

Viking-age archaeology is unquestionably interdisciplinary in nature. Yet scholars differ widely in how to integrate different sources of evidence. Depending on scholarly traditions and the particular character, date, and location of the data under consideration, mortuary data from the period is treated by some as prehistoric, by other scholars as proto-historic, and by others still as fully within the bounds of historical enquiry drawing directly on contemporary and later literature. The varying intersections between disciplinary traditions — theoretical and methodological - affect the interpretation of the period's burial and memorial evidence. For instance, there remain different camps of scholars who wish to write burial archaeology informed by the sagas (discussed and debated by, among others, Pétursdóttir, 2009; Price, 2010; Gardeła, 2016) and those who situate the data historically but very much from the ground up (e.g. Artelius, 2005; Rundkvist, 2011). Another way of framing this interpretative spectrum is between those who write about mortuary practices using elite performances and the tenth-century account of Ibn Fadlan and other written sources as entry points into the study of mortuary process and variability (Price, 2010) and those who draw more directly from ethnographic and ethnoarchaeological data and broader anthropological and sociological literature on death, dying, and commemoration (e.g. Back Danielsson, 2009; Oestigaard, 2013).

These are overlapping rather than oppositional trends. These varied approaches underpin how investigations of belowground funerary remains, monuments, and carved stone monuments, build on, and have been informed by, a wide range of concepts and approaches. Moreover, they sometimes incorporate the work of runologists, place-name specialists, literary scholars, and historians of medieval art, landscapes, religion, society, and politics with varied emphases (e.g. Price, 2002; 2008; Thedéen, 2010). Over the last decade in particular, studies have become increasingly sensitive to identifying local and regional patterns rather than adopting a macro-regional approach (see Svanberg, 2003), attentive to the complex chronological shifts in mortuary practice within the Viking Age alongside deeper long term rhythms in mortuary and cult practice in both Scandinavia (e.g. Andrén, 2014) and areas affected by the Viking diaspora (e.g. Hadley, 2008). Finally, there 
is a long tradition of integrating mortuary data alongside other lines of archaeological evidence including art, artefacts, settlements, and hoards (e.g. Dobat, 2008; Hedeager, 2011).

\section{Death and Memory in the Viking World}

The Viking Age has been considered a time particularly obsessed with the working and reworking of senses of the past. Among recent studies, a growing number of archaeologists have attempted to theorize, explore, and interrogate a range of media and contexts as evidence for relationships between mortuary practice, memory-making, and mythology (Andrén, 1993; Arwill-Nordbladh, 2007; Price, 2010). In addition to rune-inscribed monuments upon which aspirations of remembrance on the part of the commissioners and those being commemorated are clearly exhibited, archaeologists are becoming increasingly sensitive to the fact that texts were elements of broader networks of commemorative strategies drawing on embodied performances; memory was created through and between funerals, using material culture, abstract art, images, monuments, and landscape. These approaches have different theoretical starting points and have adopted different methodologies, yet they are in broad agreement in regarding mortuary practice as pivotal (or at least not incidental) in the creation and reproduction of social memories and mythologies; in other words how communities in Scandinavia and elsewhere in the Viking world constructed and negotiated senses of identity, belonging, and links to imagined and recalled pasts (see Williams, 2006; Price, 2010).

Two foci have driven research, both attempting to refine how death rituals operated in relation to local patterns and landscapes as well as broader trends (Svanberg, 2003). First are studies of the 'past in the past', including the reuse of ancient monuments (Hallans Stenholm, 2006; Pedersen, 2006; Harrison, 2007; Thäte, 2007a; 2009; Artelius, 2013) but also the consideration of artefact biographies explored by paying attention to 'heirlooms' and other retrieved or curated material cultures deployed in graves and other commemorative environments (Artelius \& Lindqvist, 2005; Wessman, 2007; 2010; Myrberg, 2009; Pétursdóttir, 2009; Arwill-Nordbladh, 2013).

Yet the study of social memory through archaeological data has been broadened beyond the study of monument reuse and artefact biographies to consider a range of other ways by which Late Iron Age (early medieval) communities socially remembered and forgot through the practices and theatrics of mortuary performances and environments. Such approaches focus on the staged and sequential display and consignment of material culture, not simply heirlooms but also more modest artefacts and their interaction with the dead and mourners (Pétursdóttir, 2009; Price, 2010; 2014). Furthermore, attempts have been made to consider the entangled nature of mortuary assemblages and their interplay with other media including monumentality, space, and landscape more broadly (Gansum \& Oestigaard, 2004; Artelius, 2005; Jennbert, 2006; Kristoffersen \& Oestigaard, 2008; Back Danielsson, 2010; Wessman, 2010; Price, 2014; Williams, 2014).

A particular shared dimension of recent approaches is their concern with processes of corporeal transformation. This takes attention away from the study of mortuary symbolism mediated by the presence and display of material culture (especially discussed for wellpreserved and well-furnished inhumation graves). Instead, it allows archaeologists to 
consider other mnemonic practices such as fire rituals including, but extending beyond, cremation (e.g. Høilund Nielsen, 2009; Wessman, 2010; Artelius, 2013; Williams, 2013). The mnemonic interplay of different mundane practices and pyrotechnologies in the transformation of the dead, including cooking, weaving, and metalworking has led to particularly fruitful interpretations (Gansum, 2004a; 2004b; Back Danielsson, 2007; Goldhahn \& Oestigaard, 2008; Oestigaard, 2013). Other key aspects of these approaches, not always framed in relation to social memory but with the potential to do so, include the interplay between animals and people in mortuary practice (Back Danielsson, 2007; Price, 2010; Hedeager, 2011; Jennbert, 2011) and the material and sensory affordances of those substances, artefacts, and structures deployed in dealings with the dead (e.g. Artelius \& Lindqvist, 2005; Back Danielsson, 2007; Lindgren, 2008; Thedéen, 2010; Andrén, 2014).

The mnemonic approach to burial and memorial data also allows archaeologists and other scholars to reconsider a range of dimensions of early medieval mortuary practice, from the use of ephemeral architectures (Williams, 2014; Wessman \& Williams, forthcoming) to the perception of the dead as corporeal inhabitants of their graves and the reinterpretation of 'grave-robbing' (Klevnäs, 2007; 2015; Bill and Daly, 2012; Gardeła, 2013). These studies have considered mortuary practices and monuments as engines of memory: mnemonic mechanisms driving perceptions of the past and social change into the future (Williams, 2006; Back Danielsson, 2007). In these ways, Viking-age mortuary and commemorative practices can be re-framed as concerning the interplay between what Connerton (1989) called 'incorporating practices' and 'inscribing practices' (see also Arwill-Nordbladh, 2013). These allow us to explore themes in mortuary practice in relation to pre-Christian and conversion period communities (Lund, 2013).

This brings us back to inscription, and further work has explored the dynamic interplay between these material practices of memory work and textual strategies of remembrance. The interactions between text, art, image, and monumentality in social remembrance is thus a key dimension of Viking-age mortuary archaeology (Andrén, 1993; 2000; Staecker, 2006; Arwill-Nordbladh, 2007; Back Danielsson, 2007; 2015). Back Danielsson (2015) has considered, for example, the mnemonic effects of rune-stone placement and the embodied interactions their runes and zoomorphic imagery contrive. She also considers the broader landscapes within which mortuary contexts were situated (see also Williams et al., 2010; Williams, 2011). The commemorative dimensions of materiality and patterns of landscape positioning and relationships between settlements, cemeteries, and other locales have also been considered in terms of mythology and memory (Thäte, 2007a; 2007b; 2009; Larsson, 2010; Hedeager, 2011; Andreeff, 2012; Andrén, 2014).

Much of this literature explicitly critiques the bracketing of mortuary archaeology from other social realms and some studies have actively sought to explore mortuary mnemonics in contexts not traditionally regarded as funerary, including settlements (e.g. Thäte, $2007 \mathrm{~b}$; Larsson, 2010; Eriksen, 2013), hoards (Myrberg, 2009), and the life-histories of artefact types in relation to the living and the dead (e.g. Ashby, 2014). Further dimensions to such contextual approaches include explorations of the spatial interpolation between dwellings, practices, and graves and the biographies of monuments as they shift between mortuary, commemorative, and other uses through their 'life-history' (Burström, 1996; Bill \& Daly, 2012; Rundkvist, 2012; Hall, 2015). 


\section{Challenges for Viking-Age Mortuary Archaeology}

So far, I have identified a multidisciplinary context straddling many kinds of data that inform the study of the past and social memory in the Viking world, focusing in particular on studies that explore the entanglement of mortuary practices within broader material worlds and investigate the interconnected facets of mortuary technologies as commemorative strategies with both social and mythological dimensions. Yet there remain key challenges for future research.

Even among this literature, few acknowledge, let alone tackle critically, recent approaches to social memory in mortuary archaeology and instead prefer to retreat into the anthropology and history of religion and a perception of cosmology and mythology. In short, studies of memory remain overly straightjacketed by attempts to search for either 'Viking minds' (see Price, 2002; 2010; 2014) or social structure (see Dobat, 2008). I have discussed my reservations towards the search for meaning and mind elsewhere (Williams, 2010; 2013; see also Back Danielsson, 2007) and advocated the need to balance between seeing mortuary practices and commemoration as neither mirror nor mirage (Williams \& Sayer, 2009). In this regard, Viking-age mortuary practice can gain from drawing on more careful work on later prehistoric and early historic mortuary practices elsewhere, exemplified by the pairing of book-length studies of a decade ago by this author (Williams, 2006) and Jones (2007). Jones in particular draws on anthropological theories of memory to explicitly engage with the theme of citation, and 'citational fields' connecting sequential depositional practices, the use of transforming fire technologies, and the structure and development of mortuary monuments.

A further constraint consists of a geographical fissure in the theoretical frameworks applied to Viking-age mortuary and commemorative practice. In stark contrast to the vibrant debates in Scandinavian and Baltic archaeology (see Wessman, 2010), in the North Atlantic and Insular world this mythological metanarrative for social memory is only found within studies of stone sculpture (e.g. Kopár, 2012; Williams et al., 2015) and rarely considered for other categories of data (Pétursdóttir, 2009). Elsewhere, it is largely supplanted by historical approaches; the meta-narrative of the written sources of Norse raiding, trading, settlement, and the processes by which mortuary practice was influenced and inspired by external and internal forces (see critiques by, among others, Staecker, 2005 and Pétursdóttir, 2009). Moreover, memory work is often simplified to active assertions of otherness and Norseness by immigrant elites in the colonial environment (e.g. Williams, 2006; Hadley, 2008). While undoubtedly part of the narrative, this risks being a reductive approach. Hence, while Scandinavian archaeologists have more rigorously theorized mortuary archaeology, both Insular and Scandinavian research suffer by being somewhat silenced by a colonial discourse, despite extensive critique of this challenge over a decade ago by Svanberg (2003). Back projecting historical narratives or mythological schemes offer invaluable interpretative possibilities for interpreting Viking-age mortuary performances and their possible meanings, but they equally risk silencing the narratives garnered from the material culture and the past lives of individuals and communities they implicated, as well as suppressing the detailed contextual stories of people, places, and memory revealed in the complex and varied dimensions over time and space (see Rundkvist \& Williams, 2008; Williams, 2006; 2013; 2014; Williams et al., 2010). The issue here is one of 
scale: our collective research aspiration should be balanced between micro-narratives relating to specific places and sites, and macronarratives that subsume all variability into a common interpretative schema. In doing so, we need to enhance dialogues between studies of mortuary and commemorative practices among the Vikings 'at home' and 'abroad'.

This problem is accentuated by specialist divisions among researchers, including distinctive camps of scholars working on rune-stones, picture-stones, burial archaeology, art, and artefacts, each attending discrete conference venues and opting for different publication outlets. Hence, many of the more innovative studies are found subsumed within either multi-period themed collections or period-specific volumes in which description takes precedent over theoretical debate and interpretation. Increasingly, studies are escaping these spatial, chronological and disciplinary ghettos (notably Back Danielsson, 2007; Price, 2010; Andrén, 2014), and yet they face the challenge of being isolated case studies in the application of theoretical approaches. Remarkably, and quite surprisingly given the widespread use of mortuary-derived material cultures in popular syntheses of the Viking Age, there are no collections spanning both Scandinavia and elsewhere in the Viking world that attempt to build new theoretical approaches in the study of mortuary practice.

\section{Mortuary Citations Defined}

This situation provided the direct inspiration for this special issue, confirmed and complemented by a recent collection which focuses firmly on rethinking the entanglement of things and spaces within 'Viking worlds' (Eriksen et al., 2015). Therefore, this collection seeks to tackle death, memory, and material culture in a specific set of ways. While we would not claim that a citational approach to social memory is the only profitable direction for mortuary research in the late first millennium $A D$, this collection provides a range of voices and perspectives on this important theme, confronting different material and contexts, and a wide span of regions and locales. In doing so, the studies recognize the importance of tracing the biographies of specific categories of things and the entanglement of people and things created through the movement and transfer of things over time (e.g. Ashby, 2015), as well as the networks of memory forged by cultural practices including poetry and commemorative expressions through ritual, art, and monuments (e.g. Jesch, 2015). Thinking about citational fields as proposed by Jones (2007) takes us further than simply a recognition of artefact biographies and the material qualities of things. It helps us to think about selective and cumulative relationships between categories and finds, and transcend the usual divide between below-ground burial data and aboveground monuments and memorials, as well as between Viking 'homelands' and zones of Norse trading, raiding, and settlement (see also Back Danielsson, 2007). The European Journal of Archaeology is an ideal venue for this collection, since it serves to use the archaeology of the Viking Age not only to gain new insights into these societies in these regions, but to demonstrate potential synergies with comparable work on death, memory, and material culture in other periods and regions of European and world archaeology.

Drawing on recent theoretical approaches to memory, personhood, and materiality in prehistoric, early historic, and late historic mortuary archaeological 
research, the specific focus of this collection is mortuary citation (see also Williams, 2006). This is defined here as practices of selection and deployment of artefacts, substances, images, architectures, monuments, and spaces that, separately and in combination, created mnemonic material references to other things, places, peoples, and times. In this way, as recently discussed by Jesch (2015), senses of shared pasts and identities were congealed an reformulated. While citations are replete in Viking-age monumental texts (runes), commemorating relationships between living and dead family members and their aspirations to land, power, faith, and identity, the power of citations created a field linking many different material categories.

The theme of mortuary citation presents new perspectives on each specific category of mortuary material - burials and cemeteries, inscribed and sculpted stone monuments as well as to emphasize relationships between them and the broader material worlds in which these contexts and materials operated. It focuses on death and memory as practical, embodied engagements between the living and the dead that may have dramaturgical components, but they might have equally involved routinized work and less organized, improvised and ad hoc practices. This approach helps us navigate between seeing Vikingage mortuary practices as either mirror or mirage (see above). Instead of opting for either of these interpretative directions, we can explore mortuary practices as varied, unfolding context-specific strategies of memory work.

Such a way of proceeding aims to critique the theoretically disengaged nature of many existing traditions of studying death-ways and also to challenge the treatment of burials and monuments as fixed, singular, and sealed contexts and things. The collection's aim is to re-engage with Viking-age mortuary practice and commemoration relationally and contextually, situated within a web of mnemonic citational relationships to other contemporary and past material cultures and spaces. This approach explores the connections between bodies, materials, texts, art, monuments, spaces, and landscapes implicated in mortuary disposal methods and monumentalities in terms of cultural choices, biographical linkages, and technological sequences. Instead we can explore the networks by which memory was worked and reworked through the interplay of materialities and spatialities created through the mortuary environment (see Williams, 2006; Back Danielsson, 2007; Jones, 2007; Williams et al., 2010; Gardeła, 2016). Furthermore, this approach not only sheds new light on the specific form, decoration, materialities, and biographies of specific materials, artefacts, monuments, and spaces employed in the commemoration of the dead during the Viking Age, but it also helps researchers understand how mortuary assemblages operated together and in relation to each other in unfolding traditions of memory work. From the investigation of skeuomorphism, scalar transformations (miniaturization, gigantism), the mnemonic power of assemblages of artefacts and monuments, and the citational power of images, materials, and landscapes, this approach offers new perspectives and insights into the death rituals of the creolizing and syncretistic death rituals of Fennoscandia, the British Isles, and the North Atlantic during the period of the Viking diaspora.

\section{Mortuary Citations Explored}

The contributions have been arranged to take readers on a journey through themes, time, geography, and contexts. We begin with Lund and Arwill-Nordbladh who together explore 
a definition of citation for mortuary contexts by investigating spatial relationships within two elite landscapes. They investigate the ancient monuments, settlement, hoarding practices, and mortuary display at Gamla Lejre in Zealand, Denmark, and how the unfolding practices of dwelling and disposal accrued an elite topography of memory through repeated material citations and a pastiche of performances. Complementing the attention given to the topography of memory, they move on to another elite landscape to explore the material citations within an elite ship-cremation beneath a monumental burial mound at Skopintull on the island of Adelsö in Lake Mälaren in Sweden. Here they focus on the roles of sacrificed animals, human hair, and a bird's egg in the social construction of memory during the mortuary process itself. Each case study independently reveals the construction of citational fields within the material cultures deployed during Viking-age mortuary performances. Together, these case studies show the potential of exploring citations within funerary rituals and in the longer-term development of specific landscapes drawing on a range of types of evidence.

Their study is balanced by Hall who focuses on grave goods linked to a specific set of elite mortuary practices: the deposition of gaming pieces with the dead. Spanning the Viking world from Estonia to Orkney, this phenomenon allows him to focus on the habitual practices of gaming and how these have informed the mortuary deposition of gaming pieces as a strategy of articulating elite identities, social memories, mythologies, and aspired afterlife destinations. For Hall, the deposition of gaming artefacts cited a craft of embodied knowledge and practices for Viking-age elites.

These two studies share a focus on acts of making memories through depositional practices. Klevnäs takes an alternative perspective. While she again focuses on elite furnished burials, her attention is drawn to interpreting the reopening and reworking of older graves ('grave-robbing') as a form of mortuary citation. Aimed at the public despoiling of graves and the retrieval of artefacts with biographies, these acts forged new relationships between the living and the dead.

Together, the articles thus far have in common the consideration of the intersection of material worlds and landscapes with the mortuary arena. Eriksen focuses on citations linking the mortuary and domestic arenas. She looks beyond the grave and memorials to reinterpret the Late Iron Age and Viking Age house as a mnemonic entity for households and communities and to examine the buildings themselves as non-human personalities commemorated after their 'deaths' through burning, dismantling, and covering with mounds. Her approach considers mortuary citations linked to practices of burying houses and burials associated with them.

Our collection then considers carved stone monuments. Williams looks at scalar and skeuomorphic citations in the recumbent grave-covers from northern Britain known as 'hogbacks'. Their architectural allusions and beastly guardians are regarded, not in terms of single sources of influence, but instead in relation to a network of citations to buildings, shrines, and canopies, and also to a wide range of portable artefacts from dress accessories to weaponry. Rather than specific citations to exclusive forms and concepts, here it is the range of allusions that is key to the commemorative efficacy of hogbacks and the range of audiences to whom they spoke. 


\section{Conclusion}

Unquestionably this collection cannot address all pertinent material and debates and there are inevitable geographical lacunae. Still, together these articles reveal many new directions available to archaeological research by focusing on the theme of mortuary citation. Back Danielsson wraps up the current discussion by identifying an explicit framework for developing post-humanist theory in relation to the citational theme and applying it to the Late Viking Age of Scandinavia. In doing so, her commentary and appraisal emphasizes the many new directions awaiting exploration for both seemingly familiar and new analyses and discoveries.

\section{Acknowledgements}

This special issue would not have been possible without research funding from the Department of History and Archaeology, University of Chester. The research leading to these results has received funding from the European Research Council under the European Union's Seventh Framework Programme (FP/2007-2013)/ERC Grant Agreement n. 284085. In addition to my thanks to all authors for agreeing to contribute, I would like to thank my Pilsen and Stockholm session co-organizer Dr Nanouschka Myrberg Burström who initiated the idea of the conference themes. This article has benefited from invaluable comments by Ing-Marie Back Danielsson and Marianne Hem Eriksen.

\section{References}

Andreeff, A. 2012. Archaeological Excavations of Picture Stone Sites. In: M.H. Karnell, ed. Gotland's Picture Stones. Bearers of an Enigmatic Legacy. Reports from the Friends of the Historical Museum Association, 84. Visby: Gotlands Museum, pp. 129-44.

Andrén, A. 1993. Doors to Other Worlds: Scandinavian Death Rituals in Gotlandic Perspectives. Journal of European Archaeology, 1:33-56.

Andrén, A. 2000. Re-reading Embodied Texts - An Interpretation of Rune-stones. Current Swedish Archaeology, 8:7-31.

Andrén, A. 2014. Tracing Old Norse Cosmology: The World Tree, Middle Earth, and the Sun in Archaeological Perspectives. Lund: Nordic Academic Press.

Artelius, T. 2005. The Revenant by the Lake. Spear Symbolism in Scandinavian Late Viking Age Burial Ritual. In: T. Artelius \& F. Svanberg, eds. Dealing with the Dead: Archaeological Perspectives on Prehistoric Scandinavian Burial Ritual. Stockholm: National Heritage Board, pp. 261-76.

Artelius, T. 2013. Making History: Ritual Variation in Pre-Christian Viking Age Reuse of Bronze Age Monuments in Halland, South-Western Sweden. In: S. Bergerbrant \& S. Sabatini, eds. Counterpoint: Essays in Archaeology and Heritage Studies in Honour of Professor Kristian Kristiansen. BAR International Series 2508. Oxford: Archaeopress, pp. 339-49. 
Artelius, T. \& Kirstensson, A. 2005. A Symbolic Farewell to Nature: Fencing at Late Viking Age Burial-Grounds. In: T. Artelius \& F. Svanberg, eds. Dealing with the Dead:

Archaeological Perspectives on Prehistoric Scandinavian Burial Ritual. Stockholm: National Heritage Board, pp. 173-86.

Artelius, T. \& Lindqvist, M. 2005. Bones of the Earth - Imitation as Meaning in Viking Age Burial Ritual. Current Swedish Archaeology, 13:25-38.

Arwill-Nordbladh, E. 2007. Memory and Material Culture - The Rune-Stone at Rök. In: U. Fransson, M.M. Svedin, S. Bergerbrant \& F. Androshchuk, eds. Cultural Interaction Between East and West: Archaeology, Artefacts and Human Contacts in Northern Europe. Stockholm Studies in Archaeology 44. Stockholm: Stockholm University, pp. 56-6o.

Arwill-Nordbladh, E. 2013. Golden Nodes — Linking Memory to Time and Place. In:

S. Bergerbrant \& S. Sabatini, eds. Counterpoint: Essays in Archaeology and Heritage Studies in Honour of Professor Kristian Kristiansen. BAR International Series 2508. Oxford:

Archaeopress, pp. 411-19.

Ashby, S. 2014. Technologies of Appearance: Hair Behaviour in Early Medieval Europe. Archaeological Journal, 171:151-84.

Ashby, S. 2015. What Really Caused the Viking Age? The Social Content of Raiding and Exploration. Archaeological Dialogues, 22:89-106.

Back Danielsson, I.-M. 2007. Masking moments. The transition of bodies and beings in Late Iron Age Scandinavia. PhD dissertation, Stockholm University.

Back Danielsson, I.-M. 2009. A Rare Analogy - Contemporary Cremation Practices. In: I.-M. Back Danielsson, I. Gustin, A. Larsson, N. Myrberg \& S. Thedéen, eds. Döda personers Sällskap, Stockholm Studies in Archaeology 47. Stockholm: University of Stockholm, pp. 57-8o.

Back Danielsson, I.-M. 2010. Sense and Sensibility: Masking Practices in Late Iron Age Boat-graves. In: F. Fahlander \& A. Kjellström, eds. Making Sense of Things: Archaeologies of Sensory Perception, Stockholm Studies in Archaeology 53. Stockholm: University of Stockholm, pp. 121-40.

Back Danielsson, I.-M. 2015. Walking Down Memory Lane: Rune-Stones as Mnemonic Agents in the Landscapes of Late Viking-Age Scandinavia. In: $\mathrm{H}$. Williams, J. Kirton \& M. Gondek, eds. Early Medieval Stone Monuments: Materiality, Biography and Landscape. Woodbridge: Boydell \& Brewer, pp. 6286.

Bill, J. \& Daly, A. 2012. The Plundering of the Ship Graves from Oseberg and Gokstad: An Example of Power Politics? Antiquity, 86:808-24. 
Burström, M. 1996. Other Generations' Interpretation and Use of the Past: The Case of the Picture Stones on Gotland. Current Swedish Archaeology, 4:21-40.

Connerton, P. 1989. How Societies Remember. Cambridge: Cambridge University Press.

Dobat, A. 2008. The State and the Strangers: The Role of External Forces in the Process of State Formation in Viking Age South Scandinavia (c. AD 900-1050). Viking and Medieval Scandinavia, 5:65-104.

Eriksen, M.H. 2013. Doors to the Dead. The Power of Doorways and Thresholds in Viking Age Scandinavia. Archaeological Dialogues, 20:187-214.

Eriksen, M.H., Pedersen, U., Rundberget, B., Axelsen, B.I. \& Berg, H.L., eds. 2015. Viking Worlds. Things, Spaces and Movement. Oxford: Oxbow.

Gansum, T. 2004a. The Archaeology of Earth. Current Swedish Archaeology, 12:721.

Gansum, T. 2004b. Role the Bones - From Iron to Steel. Norwegian Archaeological Review, 37:41-57.

Gansum, T. \& Oestigaard, T. 2004. The Ritual Stratigraphy of Monuments that Matter. European Journal of Archaeology, 7:61-79.

Gardeła, L. 2013. Dead or Alive? - 'Chamber Graves' and Their Inhabitants in the Old Norse Literature and Viking-Age Archaeology. In: S. Moździoch, B. Stanisławski \& P. Wiszewski, eds. Scandinavian Culture in Medieval Poland. Wrocław: Institute of Archaeology and Ethnology of the Polish Academy of Sciences, pp. 373-93.

Gardeła, L. 2016. Worshipping the Dead. Viking Age Cemeteries as Cult Sites. In: M. Egeler, ed. Germanische Kultorte. Vergleichende, historische und rezeptionsgeschichtliche Perspektiven. Münchner Nordistische Studien 24. München:

Herbert Utz, pp. 169-205.

Goldhahn, J. \& Oestigaard, T. 2008. Smith and Death - Cremations in Furnaces in Bronze and Iron Age Scandinavia. In: K. Childis, J. Lund \& C. Prescott, eds. Facets of Archaeology: Essays in Honour of Lotte Hedeager on Her 6oth Birthday, OAS 10. Oslo: Oslo Academic Press, pp. 215-42.

Gräslund, A.-S. \& Ljungkvist, J. 2011. Valsgärde Revisited. In: L. Boye, P. Ethelberg, L. Heidemann Lutz, S. Kleingärtner, P. Kruse, L. Matthes \& A. B. Sørensen, eds. Arkæologi $i$ Slesvig/Archäologie in Schleswig. Sonderband 'Det 61. Internationale Sachsensymposion 2010 Haderslev, Denmark. Neumünster: Wachholtz, pp. 13-32.

Hadley, D. 2008. Warriors, Heroes and Companions: Negotiating Masculinity in Viking-Age England. Anglo-Saxon Studies in Archaeology and History, 15:270-84. 
Hall, M. 2015. Lifeways in Stone: Memories and Matter-Reality in Early Medieval Sculpture from Scotland. In: H. Williams, J. Kirton \& M. Gondek, eds. Early Medieval Stone Monuments: Materiality, Biography and Landscape. Woodbridge: Boydell \& Brewer, pp. 182-215.

Hållans Stenholm, A.-M. 2006. Past Memories: Spatial Returning as Ritualized Remembrance. In: A. Andrén, K. Jennbert \& C. Raudvere, eds. Old Norse Religion in LongTerm Perspectives: Origins, Changes and Interactions. Lund: Nordic Academic Press, pp. 341-45.

Harrison, S. 2007. Separated from the Foaming Maelstrom: Landscapes of Insular 'Viking' Burial. Anglo-Saxon Studies in Archaeology and History, 14:173-82.

Harrison, S. \& Ó Floinn, R. 2014. Viking Graves and Grave-Goods in Ireland. Dublin: National Museum of Ireland.

Hedeager, L. 2011. Iron Age Myth and Materiality. London: Routledge.

Hedenstierna-Jonson, C. 2015. She Came from Another Place. On the Burial of a Young Girl in Birka. In: M.H. Eriksen, U. Pedersen, B. Rundberget, B.I. Axelsen \& H.L. Berg, eds. Viking Worlds. Things, Spaces and Movement. Oxford: Oxbow, pp. 90-101.

Høilund Nielsen, K. 2009. Rituals to Free the Spirit — Or What the Cremation Pyre Told. In: D. Sayer \& H. Williams, eds. Mortuary Practices and Social Identities in the Middle Ages: Essays in Burial Archaeology in Honour of Heinrich Härke.

Exeter: University of Exeter Press, pp. 81-103.

Jennbert, K. 2006. The Heroized Dead: People, Animals and Materiality in Scandinavian Death Rituals, AD 200-1000. In: A. Andrén, K. Jennbert \& C. Raudvere, eds. Old Norse Religion in Long-term Perspectives: Origins, Changes and Interactions. Lund: Nordic Academic Press, pp. 135-44.

Jennbert, K. 2011. Animals and Humans: Recurrent Symbiosis in Archaeology and Old Norse Religion. Lund: Nordic Academic Press.

Jesch, J. 2015. The Viking Diaspora. London: Routledge.

Jessen, M.D., Holst, M.K., Lindblom, C., Bonde, N. \& Pedersen, A. 2015. A Palisade Fit for a King: Ideal Architecture in King Harald Bluetooth's Jelling. Norwegian Archaeological Review, 47:42-64.

Jones, A. 2007. Memory and Material Culture. Cambridge: Cambridge University Press.

Klevnäs, A. 2007. Robbing the Dead at Gamla Uppsala, Sweden. Archaeological Review from Cambridge, 22:24-42. 
Klevnäs, A. 2015. Abandon Ship! Digging Out the Dead from the Vendel Boat-graves. Norwegian Archaeological Review, 48:1-20.

Kopár, L. 2012. Gods and Settlers: The Iconography of Norse Mythology in AngloScandinavian Sculpture. Turnhout: Brepols.

Kristoffersen, S. \& Oestigaard, T. 2008. 'Death Myths': Performing of Rituals and Variation in Corpse Treatment during the Migration Period in Norway. In: F. Fahlander \& T. Oestigaard, eds. The Materiality of Death: Bodies, Burials and Beliefs. BAR International Series S1768. Oxford: Archaeopress, pp. 155-60.

Larsson, L. 2010. Memories of Features, Memories in Finds. The Remembrance of the Past in Iron Age Scandinavia. In: K.T. Lillios \& V. Tsamis, eds. Material Mnemonics. Everyday Memory in Prehistoric Europe. Oxford: Oxbow, pp. 174-87.

Lindgren, C. 2008. Stones and Bones: The Myth of Ymer and Mortuary Practices with an Example from the Migration Period in Uppland, Central Sweden. In: F. Fahlander \& T. Oestigaard, eds. The Materiality of Death: Bodies, Burials and Beliefs. BAR International Series S1768. Oxford: Archaeopress, pp. 155-60.

Ljungkvist, J. 2008. Valsgärde: Development and Change on a Burial Ground over 1,300 years. In: S. Norr, ed. Valsgärde Studies: The Place and Its People, Past and Present. Uppsala: Department of Archaeology and Ancient History, Uppsala University, pp. 13-56.

Lund, J. 2013. Fragments of a Conversion: Handling Bodies and Objects in Pagan and Christian Scandinavia AD 800-1100. World Archaeology, 45:46-63.

Myrberg, N. 2009. The Hoarded Dead. Late Iron Age Silver Hoards as Graves. In: I.-M. Back Danielsson, I. Gustin, A. Larsson, N. Myrberg \& S. Thedéen, eds. Döda personers Sällskap. Stockholm Studies in Archaeology 47. Stockholm: Stockholm University, pp. 131-46.

Nordeide, S.W. 2011. Death in Abundance - Quickly! The Oseberg Ship Burial in Norway. Acta Archaeologica, 82:7-15.

Oestigaard, T. 2013. Cremations in Cosmology and Culture. In: S. Tarlow \& L. Nilsson Stutz, eds. The Oxford Handbook of the Archaeology of Death and Burial. Oxford: Oxford University Press, pp. 459-74.

Paterson, C., Parsons, A.J., Newman, R.M., Johnson, N. \& Howard Davis, C. 2014. Shadows in the Sand. Excavation of a Viking-Age Cemetery at Cumwhitton, Cumbria. Lancaster Imprints 22. Oxford: Oxbow.

Pedersen, A. 2006. Ancient Mounds for New Graves. An Aspect of Viking Age Burial Custom in Southern Scandinavia. In: A. Andrén, K. Jennbert \& C. Raudvere, eds. Old Norse Religion in Long-Term Perspectives: Origins, Changes and Interactions. Lund: Nordic Academic Press, pp. 346-53. 
Pétursdóttir, P. 2009. Icelandic Viking Age Graves: Lack in Material - Lack of Interpretation? Archaeologia Islandica, 7: 22-40.

Price, N. 2002. The Viking Way: Religion and War in Late Iron Age Scandinavia. Uppsala: Department of Archaeology and Ancient History, Uppsala University.

Price, N. 2008. Dying and the Dead: Viking Age Mortuary Behaviour. In: S. Brink \& N. Price, eds. The Viking World. London: Routledge, pp. 257-73.

Price, N. 2010. Passing into Poetry: Viking-Age Mortuary Drama and the Origins of Norse Mythology. Medieval Archaeology, 54: 123-56.

Price, N. 2014. Nine Paces from Hel: Time and Motion in Old Norse Ritual Performance. World Archaeology, 46:178-91.

Rundkvist, M. 2007. Early Medieval Burial Studies in Scandinavia 1994-2003. In: S. Semple $\& \mathrm{H}$. Williams, eds. Early Medieval Mortuary Practices. Anglo-Saxon Studies in Archaeology and History 14. Oxford: Oxford University School of Archaeology, pp. 47-55.

Rundkvist, M. 2011. Mead-halls of the Eastern Geats: Elite Settlements and Political Geography AD 275-1000 in Östergötland, Sweden. Stockholm: Kungl. Vitterhets Historie och Antikvitets Akademien.

Rundkvist, M. 2012. The Secondary Use of Picture Stones on Gotland Prior to the First Stone Churches, with a Typology of Picture Stone Outline Shapes. In: M.H. Karnell, ed. Gotland's Picture Stones: Bearers of an Enigmatic Legacy. Reports from the Friends of the Historical Museum Association, 84. Visby: Fornsalen Publishing, Gotlands Museum, pp. $145-60$.

Rundkvist, M. \& Williams, H. 2008. A Viking Boat Grave with Amber Gaming Pieces Excavated at Skamby, Östergötland, Sweden. Medieval Archaeology, 52:69-102.

Staecker, J. 2005. The Concepts of Imitation and Translation: Perceptions of a Viking-Age Past. Norwegian Archaeological Review, 38:3-28.

Staecker, J. 2006. Heroes, Kings, and Gods.Discovering Sagas on Gotlandic Picture-Stones. In: A. Andrén, K. Jennbert \& C. Raudvere, eds. Old Norse Religion in Long-Term Perspectives. Origins, Changes, and Interactions. Lund: Nordic Academic Press, pp. 363-68.

Svanberg, F. 2003. Death Rituals in South-East Scandinavia AD 800-1000. Decolonizing the Viking Age 2. Stockholm: Almqvist \& Wiksell International.

Thäte, E. 2007a. Monuments and Minds: Monument Re-use in Scandinavia in the Second Half of the First Millennium AD. Acta Archaeologica Lundensia Series in quarto, 27. Lund:

University of Lund. 
Thäte, E. 2007b. A Question of Priority: The Re-use of Houses and Barrows for Burials in Scandinavia in the Late Iron Age (AD 600-1000). In: S. Semple \& H. Williams, eds. Early Medieval Mortuary Practices. Anglo-Saxon Studies in Archaeology and History 14, Oxford: Oxford University Committee for Archaeology, pp. 183-93.

Thäte, E. 2009. Barrows, Roads and Ridges - Or Where to Bury the Dead? The Choice of Burial Grounds in Late Iron Age Scandinavia. In: D. Sayer \& H. Williams, eds. Mortuary Practices and Social Identities in the Middle Ages: Essays in Burial Archaeology in Honour of Heinrich Härke. Exeter: University of Exeter Press, pp. 104-22.

Thedéen, S. 2010. Immortal Maidens: The Visual Significance of the Colour White in Girls' Graves on Viking-Age Gotland. In: F. Fahlander \& A. Kjellström, eds. Making Sense of Things: Archaeologies of Sensory Perception. Stockholm Studies in Archaeology 53. Stockholm: Stockholm University, pp. 103-20.

Wessman, A. 2007. Reclaiming the Past: Using Old Artefacts as a Means of Remembering. Interarchaeologia, 3:71-88.

Wessman, A. 2010. Death, Destruction and Commemoration: Tracing Ritual Activities in Finnish Late Iron Age cemeteries (AD 550-1150). ISKOS 18. Helsinki: TheFinnish Antiquarian Society.

Wessman, A. \& Williams, H. forthcoming. Building for the Cremated Dead. In: J.I. CerezoRomán, A. Wessman \& H. Williams, eds. Cremation and the Archaeology of Death. Oxford: Oxford University Press.

Williams, H. 2006. Death and Memory in Early Medieval Britain. Cambridge: Cambridge University Press.

Williams, H. 2010. At the Funeral. In: M. Carver, A. Sanmark \& S. Semple, eds. Signals of Belief in Early England: Anglo-Saxon Paganism Revisited. Oxford: Oxbow, pp. 67-83.

Williams, H. 2011. Remembering Elites: Early Medieval Stone Crosses as Commemorative Technologies. In: L. Boye, P. Ethelberg, L. Heidemann Lutz, S. Kleingärtner, P. Kruse, L. Matthes \& A.B. Sørensen, eds. Arkæologi i Slesvig/Archäologie in Schleswig. Sonderband 'Det 61. Internationale Sachsensymposion 2010 Haderslev, Denmark. Neumünster: Wachholtz, pp. 13-32.

Williams, H. 2013. Death, Memory and Material Culture: Catalytic Commemoration and the Cremated Dead. In: S. Tarlow \& L. Nilsson Stutz, eds. The Oxford Handbook of the Archaeology of Death and Burial. Oxford: Oxford University Press, pp. 195-208.

Williams, H. 2014. Memory Through Monuments: Movement and Temporality in Skamby's Boat Graves. In: H. Alexandersson, A. Andreeff \& A. Bünz, eds. Med hjärta och hjärna. En vänbok till professor Elisabeth Arwill-Nordbladh. GOTARC Series A, Gothenburg Archaeological Studies, 5. Göteborg: Göteborgs Universitet, Institutionen för historiska studier, pp. 397-414. 
Williams, H., Kirton, J. and Gondek, M. 2015. Introduction: Stones in Substance, Space and Time. In: H. Williams, J. Kirton \& M. Gondek, eds. Early Medieval Stone Monuments:

Materiality, Biography and Landscape. Woodbridge: Boydell \& Brewer, pp. 1-34.

Williams, H., Rundkvist, M. \& Danielsson, A. 2010. The Landscape of a Swedish Boat-grave Cemetery. Landscapes, 11:1-24.

Williams, H. \& Sayer, D. 2009. Halls of Mirrors: Death \& Identity in Medieval Archaeology. In: D. Sayer \& H. Williams, eds. Mortuary Practices and Social Identities in the Middle Ages: Essays in Burial Archaeology in Honour of Heinrich Härke. Exeter: University of Exeter Press, pp. 1-22. 